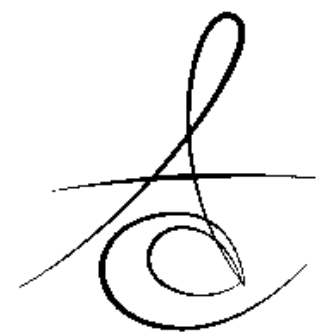

\title{
INDIRECT FIBER-REINFORCED RESIN COMPOSITE RESTORATIONS FOR MANDIBULAR ANTERIOR DENTITION (18 MONTH FOLLOW UP) ${ }^{\neq}$
}

\section{MANDİBULAR ANTERİOR DENTİSYONDA İNDİREKT FİBERLE GÜÇLENDİRİLMİŞ REZİN KOMPOZİT RESTORASYON YAPIMI (18 AYLIK TAKİP) ${ }^{*}$}

\section{ABSTRACT}

The mandibular anterior tooth loss because of trauma or periodontal problems is seen frequently. In some cases, the presence of a diastema between teeth is a common feature found in the mandibular anterior dentition. Many forms of therapy can be used for diastema closure. A carefully developed diagnosis and advanced planning allows the most appropriate treatment to address the patient's needs. Among the suggested options are for diastema closure such as orthodontic, restorative and prosthodontic treatment. The specific goals of treating diastema are: creating a tooth form in harmony with adjacent teeth, arch, and facial form; maintaining an environment for excellent gingival health; and attainment of a stable and functional occlusion. The combination of fiberreinforced resin composite technology and adhesive techniques can provide minimally invasive and costeffective treatment options for the chairside closure of dieastema and replacement of missing teeth of mandibular anterior dentition. This clinical report describes two cases that fiber-reinforced fixed partial denture was successfully used in terms of esthetic, phonetic and functionally.

Keywords: indirect restorations, adhesive bridge, fiber reinforced resin composite
ÖZET

Travma veya periodontal problemlerden dolayı mandibular anterior diş kaybına oldukça sık rastlanmaktadır. Bazı vakalarda ise santral dişler arasında bir diastema varlığı mandibular anterior dentisyonda yaygın bulunan bir durumdur. Diş eksikliğinde yapılabilecek tedavi yöntemlerinin çoğu diastema kapatılması için de kullanılabilir. Dikkatli ve gelişmiş bir diagnoz ve iyi bir planlama, hastanın ihtiyaçlarına hitap eden en uygun tedaviye izin verir. Ortodonti, restoratif ve protetik tedavi diastema kapatılması için önerilen tedavi seçenekleri arasındadır.

Diestema tedavisi spesifik hedefleri şunlardır: komşu dişler, dental ark ve yüz formu ile uyum içinde bir diş formu oluşturma; mükemmel dişeti sağlığı için uygun bir ortam sağlamak; ve stabil ve fonksiyonel okluzyon oluşturmaktır. Fiber takviyeli kompozit teknolojisi ve adeziv tekniklerin kombinasyonu tek seansta dieastema kapatılması ve mandibular anterior bölge eksik dişlerin tamamlanması için minimal invaziv ve düşük maliyetli bir tedavi seçeneği sağlayabilir. Bu klinik raporda estetik, fonetik ve fonksiyonel bakımdan başarıyla kullanılan FRC ile restore edilmiş iki olgu açıklanmaktadır.

Anahtar kelimeler: indirekt restorasyonlar, adeziv köprüler, fiberle güçlendirilmiş rezin köprüler

\section{INTRODUCTION}

Anterior tooth missing causes functional problems as well produce some esthetic problems especially in adolescent patients. Because anterior permanent teeth missing of adolescents can cause some serious physiologic situation, treatment choice obtains importance. An ideal restorative treatment can provide renewed function and esthetic, protection for remaining tooth structure and tooth surrounded tissue biologically and mechanically ${ }^{1,2}$.

*Department of Prosthodontics, Faculty of Dentistry, Atatürk University,

${ }^{\ddagger}$ This study was presented at $38^{\text {th }}$ Annual conference of European Prosthodontics Association (EPA) 25-27 September 2014, İstanbul. 
During tooth substance-conserving preparation is required, the resin-bonded fixed partial denture (FPD) become an alternative treatment for replacement of missing teeth ${ }^{3,4}$. Recently, different version of the resin-bonded FPD is produced fiberreinforced composite (FRC) ${ }^{3,5-7}$. When minimal tooth preparation is required, in patients refusing implant surgery, a FRC FPD may be used as a conservative alternative to a conventional FPD for replacement of missing tooth ${ }^{8}$.

Pröbster et al. ${ }^{9}$ reported a 5 -year success rate of $76 \%$ for the resin-bonded FPDs. Frese et al. ${ }^{10}$ reported 54-month cumulative survival rate of $72.6 \%$ after FRC FPDs in the anterior area. The use of FRC resin-bonded FPDs has been suggested because of their better adhesion to the composite luting agent, good esthetics, and physiological stiffness ${ }^{5}$.

The current case reports present the restorations of the mandibular anterior missing teeth and the diastema between mandibular central incisors with the FRC FPDs.

\section{CASE 1}

18-year-old male patient was admitted to our clinic because of the diastema between mandibular central incisors (Figures. 1 and 2). Patients were undertaken two sessions periodontal treatment before the prosthodontic treatment. Following treatment, patient was referred to prosthetic clinic by the periodontist. The anamnesis of the patient revealed that the diastema between mandibular central incisors increased until last year. Then it has been learned that it has remained stable throughout one year. Recorded mobility of mandibular central incisors was the class 1 . Possible treatment options were explained to the patient. FPD with FRC was suggested as a temporary treatment until implant treatment was performed. Also FRC FPD can splint the mandibular central teeth.

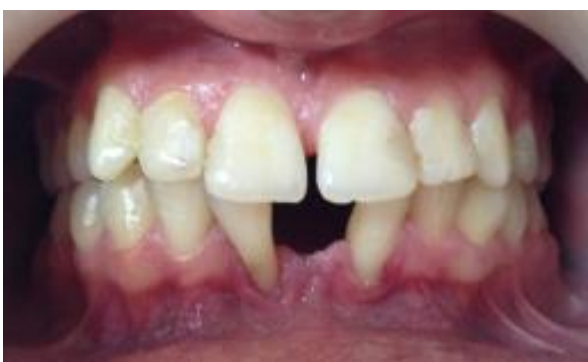

Figure 1. Pre-treatment vestibule view

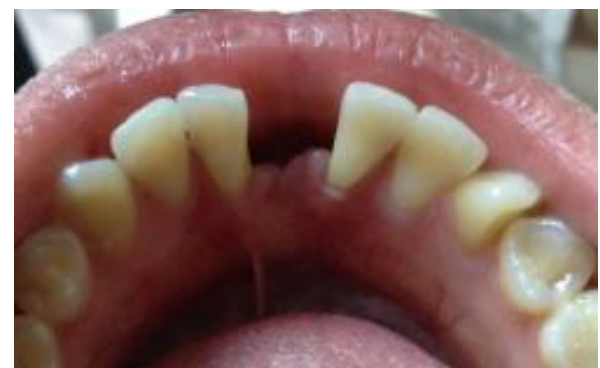

Figure 2: Pre-treatment lingual view

For the construction of a FRC FPD, mandibular impression firstly was taken with an alginate (Hydrogum 5, Zhermack SpA, Italy) impression material and color selection was done. The plaster model was obtained from impression. Acrylic teeth (Major Prodotti Dentari S.p.A, Torino, Italy) were selected and adapted in the space above the obtained plaster model. The grooves were created the lingual side of the acrylic teeth to place the fiber rods (everStick C\&B, Stick Tech Ltd. Turku, Finland). Then fiber rod was cut according to the space of between teeth (Fig. 3 and 4). Cut fiber rod was adapted in the lingual side of abutment teeth and into the grooves that prepared in acrylic teeth. Fiber rods were fixed by using a self-polymerizing acrylic resin material into the grooves of acrylic teeth. Prepared fiber-teeth complex was controlled clinically. After providing the isolation of the teeth, the lingual side of abutment teeth was etching with phosphoric acid (Total Etch, Ivoclar Vivadent AG, Schaan/Liechtenstein) during 20 second (Fig. 5), washed and dried (Fig. 6). Then fiberreinforced bridge was cemented by using a flowable composite material (Clearfil Majesty Flow, Kuraray Co Ltd. Osaka, Japon.) and self-etch adhesive system (Clearfil SE Bond, Kuraray Co Ltd. Osaka, Japon)(Fig. 7). Finally occlusion was checked and the restoration was completed after polishing (Fig. 8).

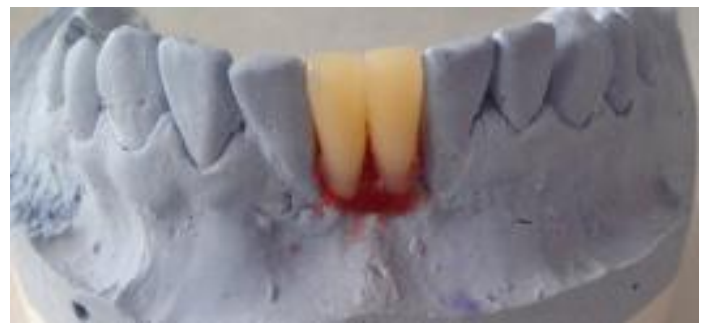

Figure 3: Acrylic teeth on the plaster vestibule view

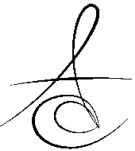




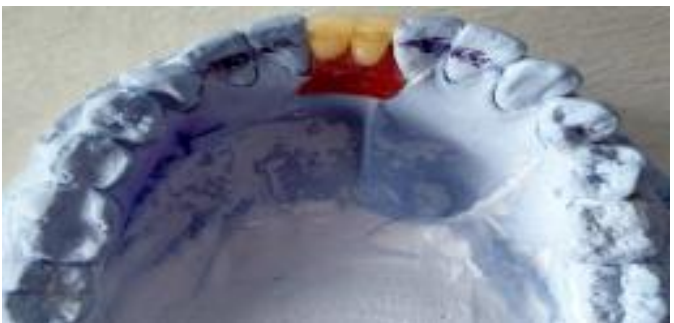

Figure 4. Acrylic teeth on the plaster model's lingual view

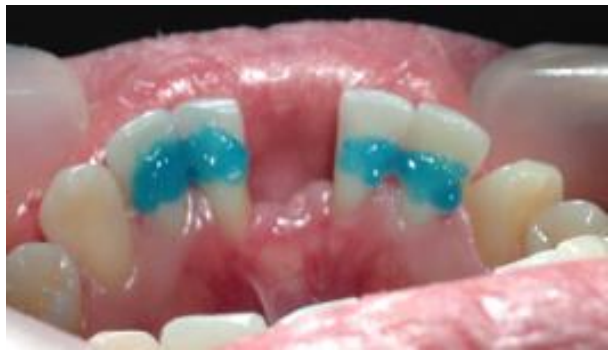

Figure 5. Etching of the lingual side of teeth

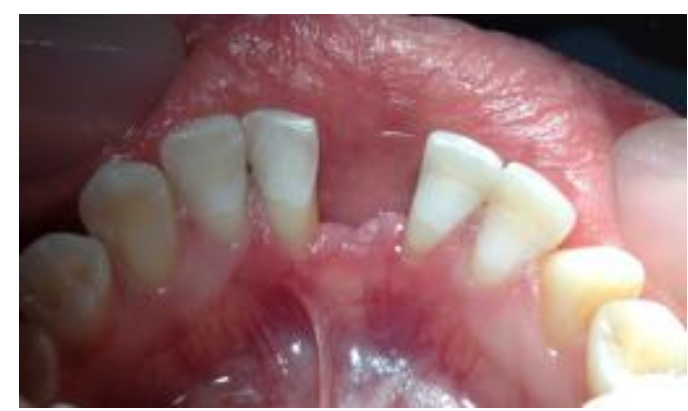

Figure 6. Abutment teeth after abutment etching

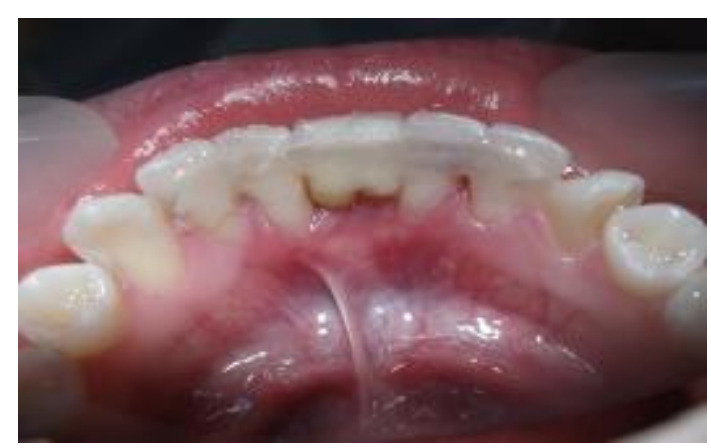

Figure 7. Lingual view after treatment

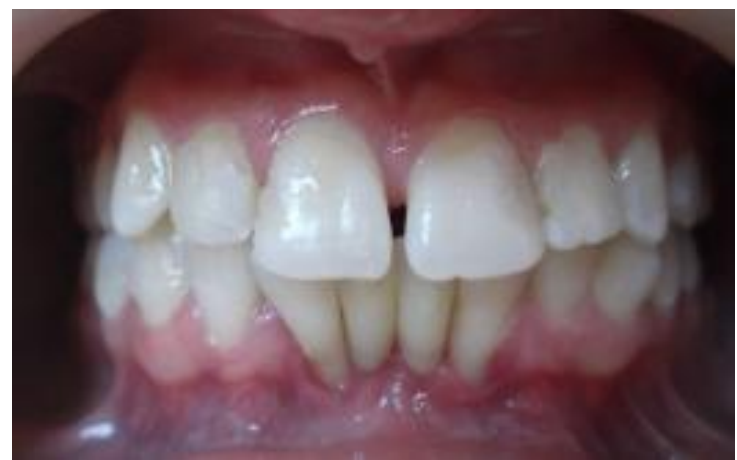

Figure 8. Vestibule view after treatment

\section{CASE 2}

17-year-old male patient was admitted to our clinic due to the lack of mandibular central incisors. The patient's dental history exhibited that lost his teeth due to trauma three weeks ago. Possible treatment options were explained to the patient. But the patient did not accept his teeth to be prepared for the construction fixed partial denture. For implant treatment the patient's age and economic situation was not appropriate. For these reason, temporary fiber reinforced bridge was applied for the patient until implant treatment.

FRC bridge construction was applied same treatment protocol as in case 1.

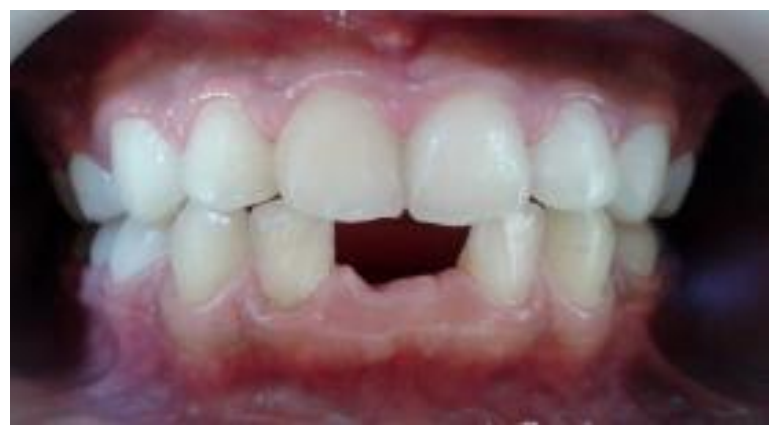

Figure 9. Vestibule view before treatment 


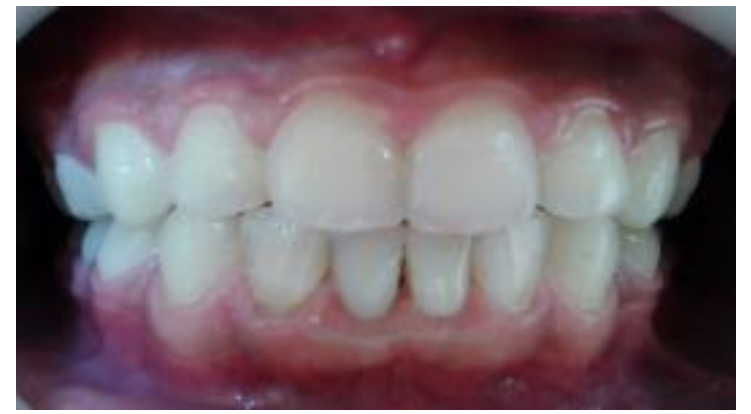

Figure 10. Vestibule view after

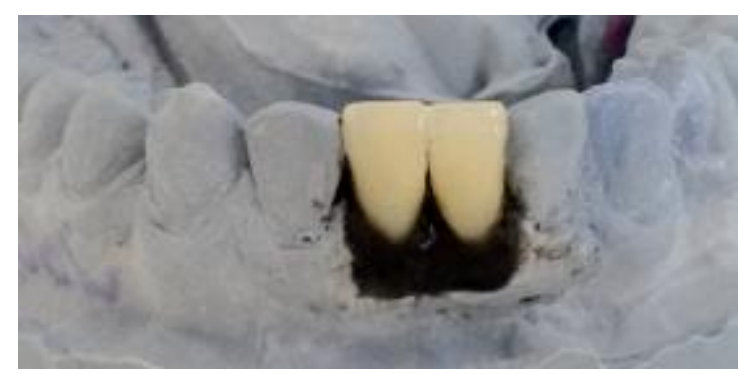

Figure 11. Acrylic teeth on the plaster vestibule view

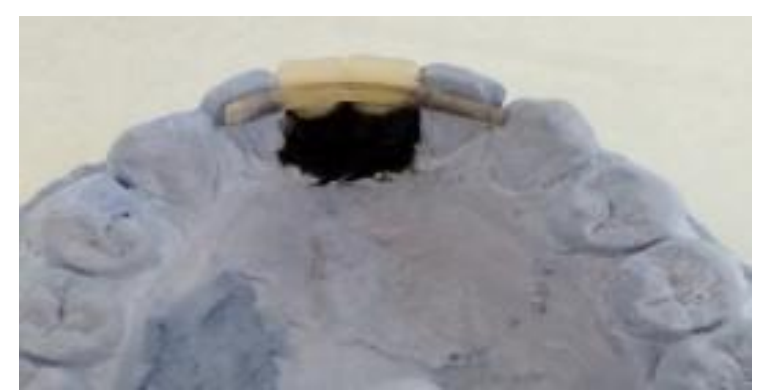

Figure 12. Acrylic teeth on the plaster model's model's lingual view

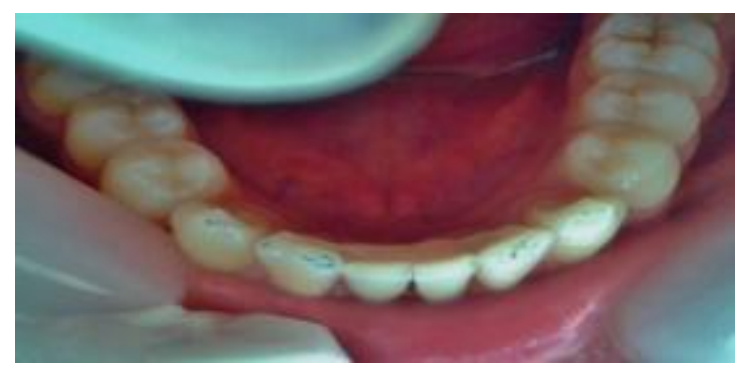

Figure13.Lingual view after treatment

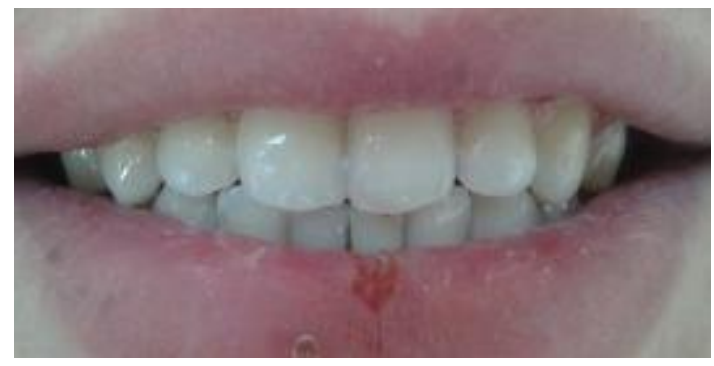

Figure14.Extra-oral view after treatment

\section{DISCUSSION}

Treatment with a resin-bonded FPD for replacement of missing teeth is a non-invasive prosthodontic treatment method ${ }^{11}$. Additionally, it can be considered as a micro invasive because of the acid etching of the enamel ${ }^{12}$. Treatment with FPDs has been reported as functioned well during a short-term evaluation period ${ }^{3,11}$.

The conventional FPDs have a little higher survival rates than resin-bonded FPDs with cast metal frameworks ${ }^{9,13,14}$. On the other hand, few studies on FPDs do not justify for comparison and verification with existed FPD results requires further clinical investigation with a strict protocol as described by Creugers et $\mathrm{al}^{13}$.

The survival rate of resin-bonded FPD is dependent on location, type, and length of the FPD ${ }^{9,13,15}$. The FRC FPD was noticeably better than that of FPDs with a metal framework as analyzed subjectively due to aesthetic translucent FRC framework ${ }^{16}$. However, it is should be underlined that FRC FPDs are not a complete replacing for the FPDs made from metal framework. Also, according to limited reported clinical studies, FRC FPDs can be a good alternative treatment option to replace only a few missing teeth than removable partial dentures. FRC FPDs might provide a less invasive FPD treatment and with somewhat lower costs than with traditional FPDs $^{3}$.

Other advantage of FRC FPDs is to allow fabrication of high-strength devices directly in the patient's mouth, thus widening treatment options. Moreover, in vitro studies have also been reported that FRC restorations have shown better fracture resistance than all-ceramic prostheses ${ }^{17}$. Injured FRC restorations can be repaired to restore their aesthetic

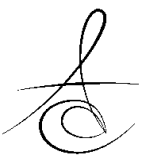


or mechanical performance ${ }^{18}$. Also, it is reported that good bond strengths for restored FRC FPDs had a fractured veneer ${ }^{19}$.

In situations in which fixed prostheses cannot be suitable because of poor prognosis of the remaining teeth or the patient's economic status is poor, the FRC FPDs may provide better treatment option for this patient. The results of previous study reported that the FRC FPDs including numerous types of retaining elements may be adequately used in the replacement of missing teeth ${ }^{5}$. On the other hand, this treatment may be contraindication to FRC FPDs for replacement of multiple missing teeth. Also, Vallittu et al. ${ }^{5}$, suggested that FRC FPDs exhibited an overall survival rate of $75 \%$ and functional survival rate of $93 \%$ after a follow-up period of 24 to 63 months.

Clinical midterm and long-term data are still insufficient for evaluation of the performance of FRC $\mathrm{FDPs}^{20-23}$. The evaluation of the quality of esthetic, functional, and biological outcomes of the FRC FDPs after 4.5 years was clinically excellent or good. In patients with good oral hygiene, direct and semi-direct fabricated FRC FDPs provide a successful treatment alternative to the replacement of single teeth in the anterior area ${ }^{10}$. This study suggested the replacement of 2 teeth with a noninvasive FRC FPDs and resulted without causing any problem in the mandibular anterior area after a follow-up the 18 months period.

In conclusion, the treatment with FRC FPDs might be better alternative option because of providing non-invasive, good esthetic, lower costs, and chairside in the replacement of missing teeth of mandibular anterior area.

\section{REFERENCES}

1. Tuğut $F$, Ünal $M$, Kapdan A, Demir H, Doğan OM. Komplike Kuron Kiriği Olgusunda Cam Fiber Post Destekli Kompozit Restorasyonu: Olgu Raporu ve 18 Aylik Takip. Atatürk Üniv Diş Hek Fak Derg 2009; 19: 207-12.

2. Baysal N, Ayyıldız S. Sabit Bölümlü Protezlerde Fiberle Güçlendirilmiş Kompozit Rezin Kullanimi. Atatürk Üniv. Diş Hek Fak Derg 2014; 24: 315-25.

3. Vallittu PK, Sevelius C. Resin-Bonded, Glass FiberReinforced Composite Fixed Partial Dentures: A Clinical Study. J Prosthet Dent 2000;84:413-8.
4. Doğan DO, Yeler D, Tuğut F. Fiberle Güçlendirilmiş Kompozit Köprü (Vaka Raporu) Cumhuriyet Üniv Diş Hek Faki Dergi 2009;12: 47-51.

5. Vallittu PK. Survival Rates of Resin-Bonded, Glass Fiber-Reinforced Composite Fixed Partial Dentures with A Mean Follow-Up of 42 Months: A Pilot Study. J Prosthet Dent 2004; 91: 241-6.

6. Vallittu PK. Case Report: A Glass Fibre Reinforced Composite Resin Bonded Fixed Partial Denture. Eur J Prosthodont Restor Dent 2001; 9: 35-8.

7. Edelhoff $D$, Spiekermann $H$, Yildirim M. Metal-Free Inlay-Retained Fixed Partial Dentures. Quintessence Int 2001; 32: 269-81.

8. Kermanshah $\mathrm{H}$, Motevasselian F. Immediate Tooth Replacement Using Fiber-Reinforced Composite and Natural Tooth Pontic. Oper Dent. 2010; 35: 238-45.

9. Pröbster B, Henrich GM. 11-Year Follow-Up Study of Resin-Bonded Fixed Partial Dentures. Int J Prosthodont 1997;10: 259-68.

10. Frese C, Schiller P, Staehle HJ, Wolff D. FiberReinforced Composite Fixed Dental Prostheses In The Anterior Area: A 4.5-Year Follow-Up. J Prosthet Dent. 2014; 112: 143-9.

11. Karaalioğlu OF, Aladağ Lì. Cam Fiber ile Güçlendirilmiş Kompozit Rezin Köprü Restorasyonu-Vaka Raporu. Atatürk Üniv Dis Hek Fak Derg 2009; 19: 111-4.

12. Vallittu PK. Prosthodontic Treatment with A Glass Fiber-Reinforced Resin-Bonded Fixed Partial Denture: A Clinical Report. J Prosthet Dent 1999; 82: $132-5$.

13. Creugers NH, De Kanter RJ, Verzijden CW, Van't Hof MA. Risk Factors and Multiple Failures In Posterior Resin-Bonded Bridges In A 5-Year MultiPractice Clinical Trial. J Dent 1998; 26: 397-402.

14. De Kanter RJ, Creugers NH, Verzijden CW, Van't Hof MA. A Five-Year Multi-Practice Clinical Study on Posterior Resin-Bonded Bridges. J Dent Res 1998; 77: 609-14.

15. Kürklü D, Yanıkoğlu ND, Sağsöz NP. Yapay Porselen Diş Kullanılarak Cam Fiberle Güçlendirilmiş Kompozit Rezin Köprü Uygulaması: 3 Olgu Raporu EÜ Dişhek Fak Derg 2010; 31: 10712.

16. Garoushi S, Vallittu P. Fiber-Reinforced Composites In Fixed Partial Dentures. Libyan J Med. 2006; 1 : 73-82. 
17. Kolbeck C, Rosentritt M, Behr M, Lang R, Handel G. In Vitro Examination of The Fracture Strength of 3 Different Fiber-Reinforced Composite and 1 AllCeramic Posterior Inlay Fixed Partial Denture Systems. Journal of Prosthodontics 2002; 11: 24853.

18. Karaalioğlu O, Duymuş ZY. Fiberle Güçlendirilmiş Kompozitlerin Sabit Bölümlü Protez Yapiminda Kullanimlari. Atatürk Üniv. Diş Hek. Fak. Derg. 2008; 18: 70-7.

19. Shi L, Fok AS. Structural Optimization of The FibreReinforced Composite Substructure In A ThreeUnit Dental Bridge. Dent Mater 2009; 25: 791-801.

20. van Heumen CC, Tanner J, van Dijken JW, Pikaar R, Lassila LV, Creugers NH, Vallittu PK, Kreulen CM. Five-Year Survival of 3-Unit Fiber-Reinforced Composite Fixed Partial Dentures In The Posterior Area. Dent Mater. 2010; 26: 954-60.

21. Freilich MA, Meiers JC, Duncan JP, Eckrote KA, Goldberg AJ. Clinical Evaluation of Fiber-Reinforced Fixed Bridges. J Am Dent Assoc. 2002; 133: 152434.

22. van Heumen CC, van Dijken JW, Tanner J, Pikaar R, Lassila LV, Creugers NH, Vallittu PK, Kreulen CM. Five-Year Survival of 3-Unit Fiber-Reinforced Composite Fixed Partial Dentures In The Anterior Area. Dent Mater. 2009; 25: 820-7.

23. Unlu N, Belli S. Three-Year Clinical Evaluation of Fiber-Reinforced Composite Fixed Partial Dentures Using Prefabricated Pontics. J Adhes Dent. 2006; 8: 183-8.

\section{Yazışma Adresi}

Prof. Dr. Funda BAYINDIR

Department of Prosthodontics, Faculty of Dentistry, Atatürk University, Erzurum, Turkey. Phone: +90 $4422360944-1751$

Fax: +904422360945

E-mail: fundabayindir(c)gmail.com 